\title{
Synthesis of flexible polyurethane foams by the partial substitution of polyol by steatite
}

\author{
Plínio César de Carvalho Pinto ${ }^{1 *}$, Virginia Ribeiro da Silva ${ }^{2}$, Maria Irene Yoshida ${ }^{1}$ and \\ Marcone Augusto Leal de Oliveira ${ }^{3}$
}

\begin{abstract}
${ }^{1}$ Departamento de Química, Universidade Federal de Minas Gerais - UFMG, Belo Horizonte, MG, Brasil ${ }^{2}$ Laboratório de Química de Nanoestruturas de Carbono, Centro de Desenvolvimento da Tecnologia Nuclear - CDTN, Belo Horizonte, MG, Brasil

${ }^{3}$ Departamento de Química, Universidade Federal de Juiz de Fora - UFJF, Juiz de Fora, MG, Brasil

*plinioccp@yahoo.com.br
\end{abstract}

\begin{abstract}
This work describes the synthesis of composites steatite/flexible polyurethane by replacing 4.5 wt. \% of polyol with steatite rock powder. We evaluated two mechanical properties of composites (comfort factor and support factor) for various formulations based on a fractional factorial design. The new synthesized composites showed higher support factor, greater comfort factor, and lower cost, compared to conventional flexible polyurethane foams. There is not a significant change in the chemical composition of the foams, due to substitution of $4.5 \mathrm{wt}$ \% polyol by steatite. However, there was a decrease in cell size and greater interaction between the hard segments of the composite.
\end{abstract}

Keywords: composites, foam, steatite, mechanical properties, polyurethanes.

\section{Introduction}

The polyurethane is a polymer which does not contain monomer unit, but is predominantly formed by urethane linkages (-HN-CO-O-). It is produced by the simultaneous reactions between an isocyanate with a polyether polyol (polimerization), Figure 1, and water (blowing), Figure 2. They are also placed in the formulation other reagents, such as catalysts, blowing agents, fillers, flame retardants and pigments ${ }^{[1,2]}$

In a few minutes, a liquid mixture of low molecular weight reactants polymerize to form a solid, the supramolecular material formed by open cells, high permeability to gases, low density and with a phase separated morphology ${ }^{[3]}$. The foams are composed of a polymeric solid phase and a air gaseous phase ${ }^{[4]}$. The solid phase has a heterogeneous separation (micro scale), often accompanied by the mixture of crystalline hard segments and amorphous soft domains ${ }^{[5]}$. The hard segments are formed by substituted ureas and urethanes, which can interact, by hydrogen bonds, due to the polar nature these bonds. The flexible domains are formed by the polyether polyol or polyester chain ${ }^{[4-6]}$. These hard segments are covalently bonded to the polyol domains by urethane linkages ${ }^{[7-8]}$.

The reversible deformation, excellent light weight, strength/weight ratio performance, comfort protection, thermal and acoustic insulating and other positive aspects of this polymeric material are the biggest selling group of polyurethanes ${ }^{[9-11]}$. The flexible foams find wide application in furniture, mattresses, upholstery, automotive seats and packing systems ${ }^{[12-13]}$. However, flexible polyurethane foam presents some undesirable features such as low thermal stability and low mechanical strengths ${ }^{[14]}$.

In this paper, we proposed the use of powdered rock steatite from Pedras Congonhas Ltd., Nova Lima, Brazil, an inorganic filler rich in talc, partially replacing the polyol in the production of flexible polyurethane foams in order to reduce costs and improve the mechanical properties of the polymer, such as support factor and comfort factor. Support factor measured by compression modulus is perhaps the most important function of flexible polyurethane foam. Foam's ability to provide support has a direct effect on other key properties such as comfort and durability. It is valid measurement of foam's cushioning ability. It also means that the foam is capable of distributing the weight of the person for maximum comfort ${ }^{[15]}$. The comfort factor is the property that measures the foams firmness. It is the ratio of the force required for an indentation disk compress the sample to $65 \%$ of its original thickness divided by the force required for an indentation disk compress the sample to $25 \%$ of its original thickness.

The mineral talc is widely used as filler in paper industry, paints, cosmetics, pharmaceuticals, refractories, ceramics, pesticides, lubricants, food industry and accident prevention, due to its properties, low hardness, whiteness, low electrical and thermal conductivity, chemical resistance and adsorption of organic substances ${ }^{[16-19]}$. Talc is also used as filler in composites, in order to improve the compound mechanical characteristics, increasing the nucleation of the polymer and the dimensional stability of the final product ${ }^{[19]}$. 


$$
\mathrm{R}^{\prime} \mathrm{N=C=O}+\mathrm{R}_{1}-\mathrm{OH} \longrightarrow \mathrm{R}-\mathrm{NH}{ }_{\mathrm{R}_{1}}
$$

Figure 1. Polimerization reaction of polyurethane.

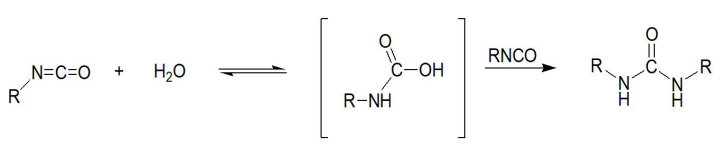

Figure 2. Blowing reaction of flexible polyurethane.

\section{Materials and Methods}

\subsection{Materials}

The production of flexible polyurethane composites used: polyether polyol Voranol 4730 Dow Chemical (polymer of ethylene oxide/propylene oxide), toluene diisocyanate Voranate T 80 Dow Chemical (80/20 blend of toluene diisocyanate isomers 2,4 and 2,6, respectively), amine catalyst Aricat AA 805 Arinos Chemistry (mixture of N, $\mathrm{N}$-diethylethanolamine and 2,2'-oxydiethanol), tin catalyst Liocat 29 Miracema-Nuodex (bis (2-ethylhexanoate) tin (II)), surfactant Niax L-540 GE Silicones (composition protected by patent) and distilled water as blowing agent.

\subsection{Sample preparation of steatite}

A steatite rock sample of Mustards Mine, New Lima, Brazil was milled for $5 \mathrm{~min}$ in a ring mill and sieved by mechanical stirring for $12 \mathrm{~h}$. The entire sample had a size smaller than 100 mesh $(<149 \mu \mathrm{m})$.

\subsection{Synthesis of flexible polyurethane composites}

In a $300 \mathrm{~mL}$ polypropylene cup were added: distilled water, surfactant, amine catalyst and polyol. It was stirred at $2000 \mathrm{rpm}$ for 1 minute by a mechanical stirrer. Steatite was added and stirred for $1 \mathrm{~min}$. Was added to the tin catalyst, stirring up again for 30 seconds. Was added toluene diisocyanate, stirring for a further 6 seconds and transferred the mixture to a wooden cubic box of $10 \mathrm{~cm}$ edge (template). After $24 \mathrm{~h}$, the foams were removed from the molds and stored to prevent the incidence of sun, wind and humidity for at least three days, for the healing. Flexible polyurethane composites were synthesized in random order by drawing lots. The formulations varied according to a fractional factorial design type $2_{V}{ }^{5-1}$ (fifth order) with five factors (variables): steatite and polyol, isocyanate, amine catalyst, tin catalyst and silicone; two levels (concentration): low -1 , high +1 ; and triplicate central point generating relationship $\mathrm{I}=12345$. This type of fractional design is of interest because the main effects will be confused with fourth order interactions (low significance), and there is no confusion between the second order interactions ${ }^{[20]}$. The water used as blowing agent was kept fixed concentration of $3.2 \mathrm{wt}$. \% to have the same density foams. The responses considered for the design were foam comfort factor and support factor. The triplicate in central point (experiments 17, 18 and 19) was used to calculate the experimental error and the significance of effects.

\subsection{Analysis of mechanical properties of the foams}

The support factor of foams measured by compression modulus was determined in a universal testing machine EMIC DL-3000, according to Brazilian standard NBR 8910:2003 (ASTM D3574 - Test C), Figure 3(a). The comfort factor determined by the indentation force deflection is determined on the same machine, according to Brazilian standard NBR 9176:2003 (ASTM D3574 - Test B1), Figure 3(b).

\subsection{Chemical and physical characterization of steatite}

The steatite is dried in an oven at a temperature of $110^{\circ} \mathrm{C}$ to a constant mass. The loss of mass due to drying is considered to be water. XRD patterns were collected with a Siemens D5000 instrument using a Ni-filtered $\mathrm{Cu}$ $\operatorname{K} \alpha$ radiation $(\lambda=1.5418 \AA)$ and a graphite monochromator in the diffracted beam. A scan rate of $1^{\circ} \mathrm{min}^{-1}$ was applied to record a pattern in the $2 \theta$ range of $5^{\circ}-80^{\circ}$. The XRD lines were encountered in JCPDS (Joint Committee on Powder Diffraction Standard). The chemical composition of steatite was determined using a Shimadzu EDX-720 Energy Dispersive X-ray Fluorescence Spectrometer. The following operating conditions were selected: voltage of $15 \mathrm{kV}$ tube $(\mathrm{Na}-\mathrm{Sc})$ and $50 \mathrm{kV}$ (Ti-U) with current in the tube 188 and $37 \mu \mathrm{A}$, respectively; in vacuum and detector $\mathrm{Si}(\mathrm{Li})$ cooled with liquid nitrogen. The quantitative method used for counting of hydroxil groups was the acetylation of a known mass sample with acetic anhydride in excess, in the presence of pyridine as solvent and imidazole as catalys ${ }^{[21]}$. The Figure 4 shows the acetylation reaction of hydroxyl containing minerals.

Infrared spectra were obtained from a Perkin-Elmer Spectrum RX FT-IR spectrometer, using $\mathrm{KBr}$ disks in the $4000-400 \mathrm{~cm}^{-1}$ region with 64 scans and $4 \mathrm{~cm}^{-1}$ of spectral resolution. Thermogravimetry (TG) and Differential Thermal Analysis (DTA) were carried out by DTG-60 Shimadsu instrument at temperatures ranging from ambient to $650{ }^{\circ} \mathrm{C}$ with a heating rate of $10^{\circ} \mathrm{C} \mathrm{min}^{-1}$ in air flow of $100 \mathrm{~mL} \mathrm{~min}^{-1}$.

\subsection{Chemical and physical characterization of foams}

It used the same conditions for the thermal analysis and infrared spectroscopy of steatite. However, infrared spectra were obtained using ATR (Attenuated Total Reflectance) configuration. In a scanning electron microscope JEOL JSM-6360LV, operating in high vacuum, images of the polymer fracture surfaces were obtained by backscattered electron. The identification of mineral or polymer phase was carried out by a EDS (Energy Dispersive Spectrometry) probe. A foam cube with edge $1 \mathrm{~cm}$ was metallized with gold to conduction electrons. The foams were sliced into $1 \mathrm{~mm}$ thick strips, with the aid of scissors and fixed on a glass slides with adhesive tape. Those glass slides were examined with a microscope Carl Zeiss Model Axioskop 40 under $25 \mathrm{x}$ magnification $(2.5 \mathrm{x}$ objective and $10 \mathrm{x}$ eyepiece) and photographed with a coupled digital Canon camera.

\section{Results and Discussions}

\subsection{Chemical and physical characterization of steatite}

It is considered in this work that a portion of the polyol may be replaced by hydroxyl-containing minerals, in order to modify the mechanical properties of flexible polyurethane 
foams. Therefore, the characterization of the steatite was performed to identify its chemical properties and also know their influence in the synthesis of polymeric composite. The Table 1 shows the chemical composition of steatite.

The Figure 5 shows $\mathrm{X}$ ray diffraction pattern and infrared spectra of the steatite.

The X-ray diffraction pattern of steatite allow us to identify the rock as composed mainly of the minerals talc $\mathrm{Mg}_{3} \mathrm{Si}_{4} \mathrm{O}_{10}(\mathrm{OH})_{2}$, clinochlore $\mathrm{Mg}_{5} \mathrm{Al}_{2} \mathrm{Si}_{3} \mathrm{O}_{10}(\mathrm{OH})_{8}$ and actinolite $\mathrm{Ca}_{2} \mathrm{Mg}_{5} \mathrm{Si}_{8} \mathrm{O}_{22}(\mathrm{OH})_{2}$. Infrared spectra of the steatite show bands that are mainly found in vibrational modes for talc phase. This indicates that it is the mineral in highest concentration in the rock. This conclusion is supported by the presence of

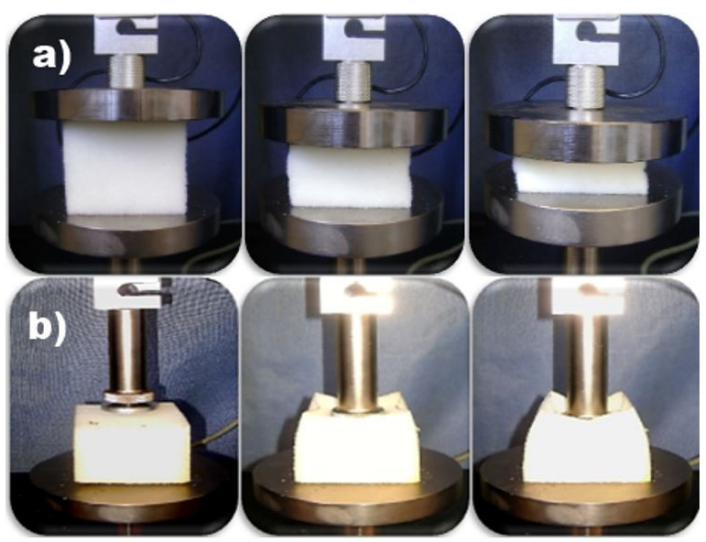

Figure 3. Mechanical test of foams Compression Modulus (a) and Indentation Force Deflection (b).

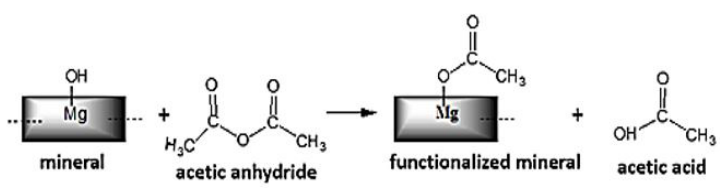

Figure 4. Acetylation reaction of the mineral $\mathrm{OH}$.

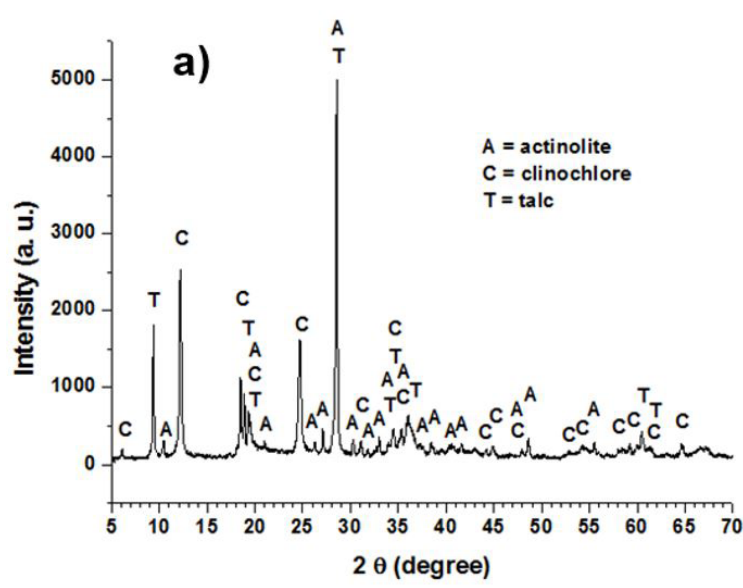

two very fine bands at $3677 \mathrm{~cm}^{-1}$ and $3661 \mathrm{~cm}^{-1}$ related to the $\mathrm{OH}$ stretching mode of talc. The enlargement of the band at $1014 \mathrm{~cm}^{-1}$ and the shoulder observed at $951 \mathrm{~cm}^{-1}$ are indicative of the presence of clinochlore. The band at $951 \mathrm{~cm}^{-1}$ is a high intensity clinochlore mode, not observed for talc ${ }^{[22,23]}$. The band at $756 \mathrm{~cm}^{-1}$ may be attributed to actinolite, related to the symmetric stretching mode of $\mathrm{Si}-\mathrm{O}-\mathrm{Si}^{[24]}$. Talc is a tri-octahedral layered mineral with each hydroxyl group linked to three octahedral cations. According to the nature of these cations, there are different frequencies for the $\mathrm{OH}$ stretching mode. The band found in the spectrum at $3677 \mathrm{~cm}^{-1}$ can be assigned to $v \mathrm{Mg}_{3} \mathrm{O}-\mathrm{H}$ mode ${ }^{[25]}$. The band at $3661 \mathrm{~cm}^{-1}$ is assigned to $v \mathrm{Mg}_{2} \mathrm{FeO}-\mathrm{H}$ mode ${ }^{[25]}$, at $3460 \mathrm{~cm}^{-1}$ to $v \mathrm{O}-\mathrm{H}$ mode of adsorbed water on the surface ${ }^{[26]}$, at $1014 \mathrm{~cm}^{-1}$ to vas $\mathrm{Si}-\mathrm{O}-\mathrm{Si}$ mode ${ }^{[22]}$, at $670 \mathrm{~cm}^{-1}$ to vs $\mathrm{Si}-\mathrm{O}-\mathrm{Si}$ mode $^{[22]}$ and the band at $463 \mathrm{~cm}^{-1}$ is assigned to out of phase translational mode of hydroxyl group with others oxygens ${ }^{[27,28]}$.

Therefore, based on the results of $\mathrm{X}$ ray diffraction and infrared spectroscopy, it follows that the hydroxyls are on a chemical environment according to the Figure $6^{[29]}$, which will react with isocianate in the polymer synthesis.

The reactivity of the hydroxyl groups present in the steatite mineral was verified by hydroxyl counting methodology for polyols used in polyurethane synthesis. The steatite features $20 \mathrm{mg} \mathrm{KOH} / \mathrm{g}$, while the polyol used in flexible polyurethane synthesis feature $34-56 \mathrm{mg} \mathrm{KOH} / \mathrm{g}^{[30]}$. In addition to this lower reactivity, the steatite presents the hydroxyl strongly linked to $\mathrm{Mg}^{2+}$ ions and $\mathrm{Fe}^{2+}$ in the crystal structure of the mineral. Therefore, the hydroxyls of steatite are in a compact and rigid structure, while the hydroxyl groups of the polyol are a flexible polymer backbone, Figure 7 .

Table 1. Chemical composition of steatite sample.

\begin{tabular}{cccc}
\hline Oxides & (wt. \%) & Oxides & (wt. \%) \\
\hline $\mathrm{MgO}$ & 30.7 & $\mathrm{~K}_{2} \mathrm{O}$ & 0.1 \\
$\mathrm{SiO}_{2}$ & 49.6 & $\mathrm{Na}_{2} \mathrm{O}$ & 0.1 \\
$\mathrm{Al}_{2} \mathrm{O}_{3}$ & 2.3 & $\mathrm{Cr}_{2} \mathrm{O}_{3}$ & 0.5 \\
$\mathrm{CaO}$ & 1.2 & $\mathrm{MnO}$ & 0.1 \\
$\mathrm{Fe}_{2} \mathrm{O}_{3}$ & 8.8 & $\mathrm{NiO}$ & 0.1 \\
\hline
\end{tabular}

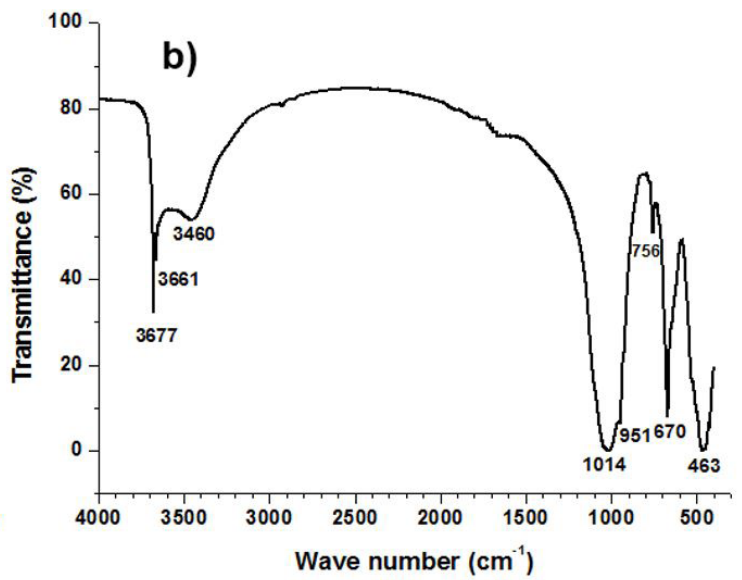

Figure 5. X ray diffraction pattern (a) and infrared spectra (b) of the steatite sample. 
Therefore, steatite minerals may also react with the isocyanate for the production of flexible polyurethane foams, Figure 8 .

In the Figure 8 it can be seen that 2,4-toluene diisocyanate is reacted with the mineral and allows the traditional polymerization (isocyanate more polyol) on the surface of

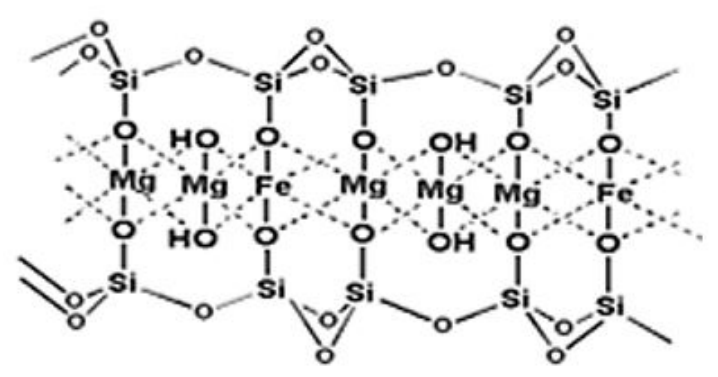

Figure 6. Talc chemical structure.

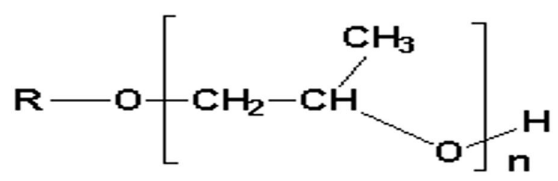

Figure 7. Representation of the polyol monomer unit. the mineral. Furthermore, minerals may be connected by covalent chemical bonds (urethane).

The humidity of steatite is $0.1 \mathrm{wt}$. $\%$. This value is very low, so it will not contribute significantly to the reaction with TDI in the synthesis of composites. The water could affect the expansion reaction and change the properties of the composite according to the Figure 2.

The steatite thermal analysis is shown in Figure 9.

Thermogravimetry of the steatite sample shows two caracteristic mass loss. The first mass loss of $3.5 \mathrm{wt}$. \%, which starts at $532{ }^{\circ} \mathrm{C}$ ending at $840{ }^{\circ} \mathrm{C}$, is related to dehydration of amphibole (actinolite) and clinochlore ${ }^{[31]}$. The second mass loss of 1.2 wt. $\%$ starts at $852{ }^{\circ} \mathrm{C}$ is related to dehydration of talc, which begins above $850^{\circ} \mathrm{C}^{[32-34]}$. The decomposition of talc is described by the following Reaction $1^{[31]}$ :

$$
\left.\mathrm{Mg}_{3} \mathrm{Si}_{4} \mathrm{O}_{10}(\mathrm{OH})_{2 \text { (talc) }} \rightarrow 3 \mathrm{MgSiO}_{3} \text { (enstatite) }\right) \mathrm{SiO}_{2 \text { (cristobalite) }}+\mathrm{H}_{2} \mathrm{O}
$$

Therefore, steatite heating at high temperature promotes the release of water, which could be an interesting feature as flame retardant ${ }^{[10-13]}$. This could hamper the composite burning in commercial applications where this property is required. However, it has not been studied.

\subsection{Foams mechanical properties}

According to a statistical analysis of Table 2, the variables isocyanate and tin catalyst have a significant effect on the foam support factor, as well as the interaction between

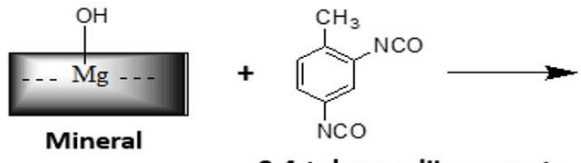

2,4-toluene diisocyanate

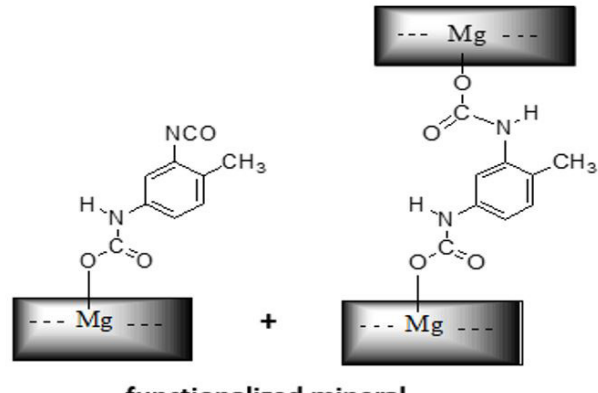

functionalized mineral

Figure 8. Reaction between the diisocyanate and the $\mathrm{OH}$ group of the mineral.

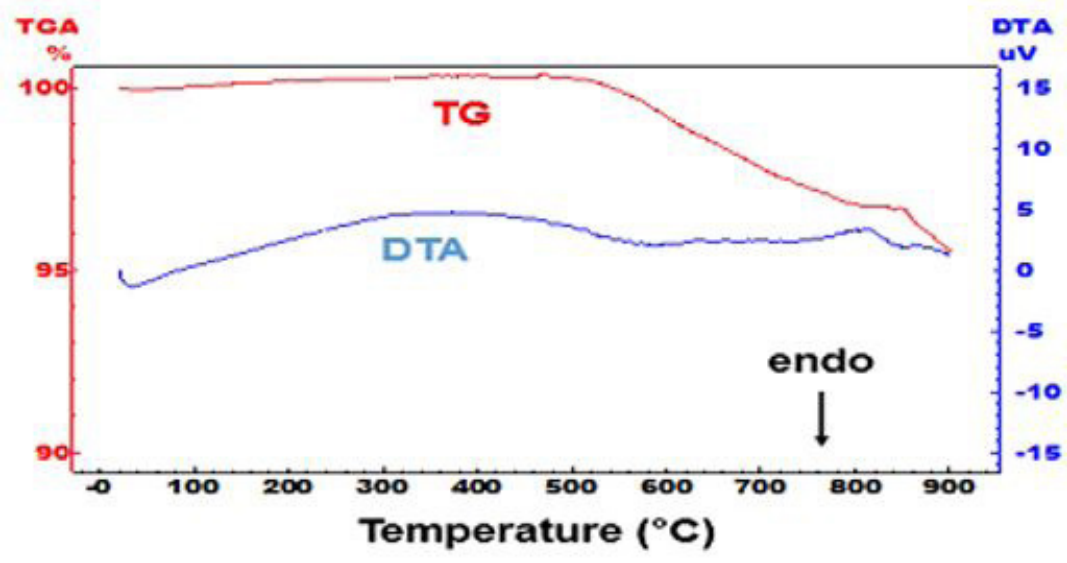

Figure 9. Steatite thermal analysis (TG and DTA). 
them. Tests 1, 2, 9 and 10 of Table 2 show that the two variables being in the lower level (isocyanate index: 105; tin catalyst: 0.1 ) generates a null response (zero) for comfort, within the range of $95 \%$ confidence for the experimental region investigated. In practice, the foam had a physical and structural defect known as crack, which prevented the realization of mechanical test. This occurred because in tests, the low concentration of isocyanate and tin catalyst did not favor the polymerization reaction. The reduction in the concentration of the reagent and catalyst displaced the equilibrium of the reaction in the direction of formation of the reactants (Figure 1). Complications arise due to the simultaneous and therefore competitive nature of the reactions of the blowing and gelation and the effect of formulation and process variability on the activation energy of these reactions ${ }^{[35]}$. The variable polyol + steatite have a significant effect on the foam support factor. Table 2 shows that increasing the amount of steatite causes an increase in support factor or hardness of the foam. Example: Test 3 compared to Test 4 ; Test 5 compared to Test 6 , successively. The increased amount of isocyanate and tin catalyst also increases the hardness of the foam by increasing both the urea phase content and the phase connections between the polyol domain and the urea segments in the polymer chain ${ }^{[2,7,36]}$. The interaction between the variables polyol + steatite and isocyanate is positive and not significant. Table 2 shows that increasing the levels of two variables (polyol + steatite: changing from 100.00 to 95.50 of polyol and 0.00 to 4.50 of steatite ; isocyanate index: changing from 105 to 125 ) simultaneously increases the foam hardness. The interaction between isocyanate and tin catalyst is negative and significant within the range of $95 \%$ confidence for the experimental region investigated. The variable silicone showed no significant effect on the properties analyzed, since the silicone acts only as a surfactant to lower surface tension, emulsify incompatible formulation ingredients, promote generation of bubbles during mixing, and stabilize cell window ${ }^{[36,37]}$. This fact confirms that the fractional factorial design used can be considered satisfactory since the variable silicone was considered little significant, within the experimental range investigated. Also, the amine, which balances and controls the expansion reaction and gelification, showed no significant effect on the mechanical properties of the formulations studied. As the 3rd order interactions (three variables) or higher orders among variables, as a rule, are not significant, these were not considered for analysis.

\subsection{Characterization of flexible polyurethane composites}

In the Figure 10 we can see that the polymer (dark mass) is formed with mineral adhered to its surface, Figure 10 ( $a, b$ and $c$ ). The polymer may also coat the mineral, according to the side section seen in Figure 10 (e). The mineral (white particle) is a magnesium silicate confirmed by EDS spectrum Figure 10 (d). This was expected, since talc $\mathrm{Mg}_{3} \mathrm{Si}_{4} \mathrm{O}_{10}(\mathrm{OH})_{2}$ is the main mineral of steatite. These observations suggest that there is a chemical interaction between the mineral and the polymer, which was identified by infrared spectroscopy. The Figure 11 shows the composite images obtained by polarized light optical microscopy.

The foams of the tests 5 and 6 have similar formulations. The difference is that the foam 5 has $100 \%$ polyol and a minimum amount of silicone. While the foam 6 has $95.5 \mathrm{wt}$ \% polyol, $4.5 \mathrm{wt} \% \%$ of steatite and the maximum amount of silicone. It is noted that foam 6 has smaller cells and more interconnected. We observed the same when comparing foams of tests 7 and 8 . They are foams with the best overall properties. As silicon shown not to influence significantly the physical properties of the foams, we attribute this morphological difference between foams for replacement of the polyol by steatite. The smaller number of hydroxyls of steatite increases the isocyanate index

Table 2. Matrix for the fractional factorial design $2_{V}^{5-1}$ to study the mechanical properties of flexible polyurethane composites with answers.

\begin{tabular}{|c|c|c|c|c|c|c|c|}
\hline \multirow[b]{2}{*}{ Tests } & \multicolumn{5}{|c|}{ Factors } & \multicolumn{2}{|c|}{ Answers } \\
\hline & $\begin{array}{c}\text { Polyol + steatite } \\
(\%)\end{array}$ & $\begin{array}{l}\text { Isocyanate } \\
\text { index }\end{array}$ & $\begin{array}{c}\text { Tin catalyst } \\
(\%)\end{array}$ & $\begin{array}{c}\text { Amine catalyst } \\
(\%)\end{array}$ & $\begin{array}{c}\text { Silicone } \\
(\%)\end{array}$ & $\begin{array}{l}\text { Comfort factor } \\
\text { (arb. unit) }\end{array}$ & $\begin{array}{c}\text { Support factor } \\
\left(\mathbf{k P a ~ m m}^{-2}\right)\end{array}$ \\
\hline 1 & $100.00+0.00$ & 105 & 0.1 & 0.6 & 0.8 & 0.00 & 0.00 \\
\hline 2 & $95.50+4.50$ & 105 & 0.1 & 0.6 & 0.6 & 0.00 & 0.00 \\
\hline 3 & $100.00+0.00$ & 125 & 0.1 & 0.6 & 0.6 & 2.55 & 3.72 \\
\hline 4 & $95.50+4.50$ & 125 & 0.1 & 0.6 & 0.8 & 2.83 & 4.91 \\
\hline 5 & $100.00+0.00$ & 105 & 0.2 & 0.6 & 0.6 & 2.46 & 3.74 \\
\hline 6 & $95.50+4.50$ & 105 & 0.2 & 0.6 & 0.8 & 2.48 & 3.38 \\
\hline 7 & $100.00+0.00$ & 125 & 0.2 & 0.6 & 0.8 & 2.54 & 4.10 \\
\hline 8 & $95.50+4.50$ & 125 & 0.2 & 0.6 & 0.6 & 2.66 & 4.87 \\
\hline 9 & $100.00+0.00$ & 105 & 0.1 & 1.0 & 0.6 & 0.00 & 0.00 \\
\hline 10 & $95.50+4.50$ & 105 & 0.1 & 1.0 & 0.8 & 0.00 & 0.00 \\
\hline 11 & $100.00+0.00$ & 125 & 0.1 & 1.0 & 0.8 & 2.73 & 3.50 \\
\hline 12 & $95.50+4.50$ & 125 & 0.1 & 1.0 & 0.6 & 3.04 & 4.61 \\
\hline 13 & $100.00+0.00$ & 105 & 0.2 & 1.0 & 0.8 & 2.41 & 3.12 \\
\hline 14 & $95.50+4.50$ & 105 & 0.2 & 1.0 & 0.6 & 2.57 & 4.30 \\
\hline 15 & $100.00+0.00$ & 125 & 0.2 & 1.0 & 0.6 & 2.65 & 3.89 \\
\hline 16 & $95.50+4.50$ & 125 & 0.2 & 1.0 & 0.8 & 2.70 & 4.56 \\
\hline 17 & $97.75+2.25$ & 115 & 0.15 & 0.8 & 0.7 & 2.75 & 4.31 \\
\hline 18 & $97.75+2.25$ & 115 & 0.15 & 0.8 & 0.7 & 2.49 & 4.34 \\
\hline 19 & $97.75+2.25$ & 115 & 0.15 & 0.8 & 0.7 & 2.47 & 4.13 \\
\hline
\end{tabular}



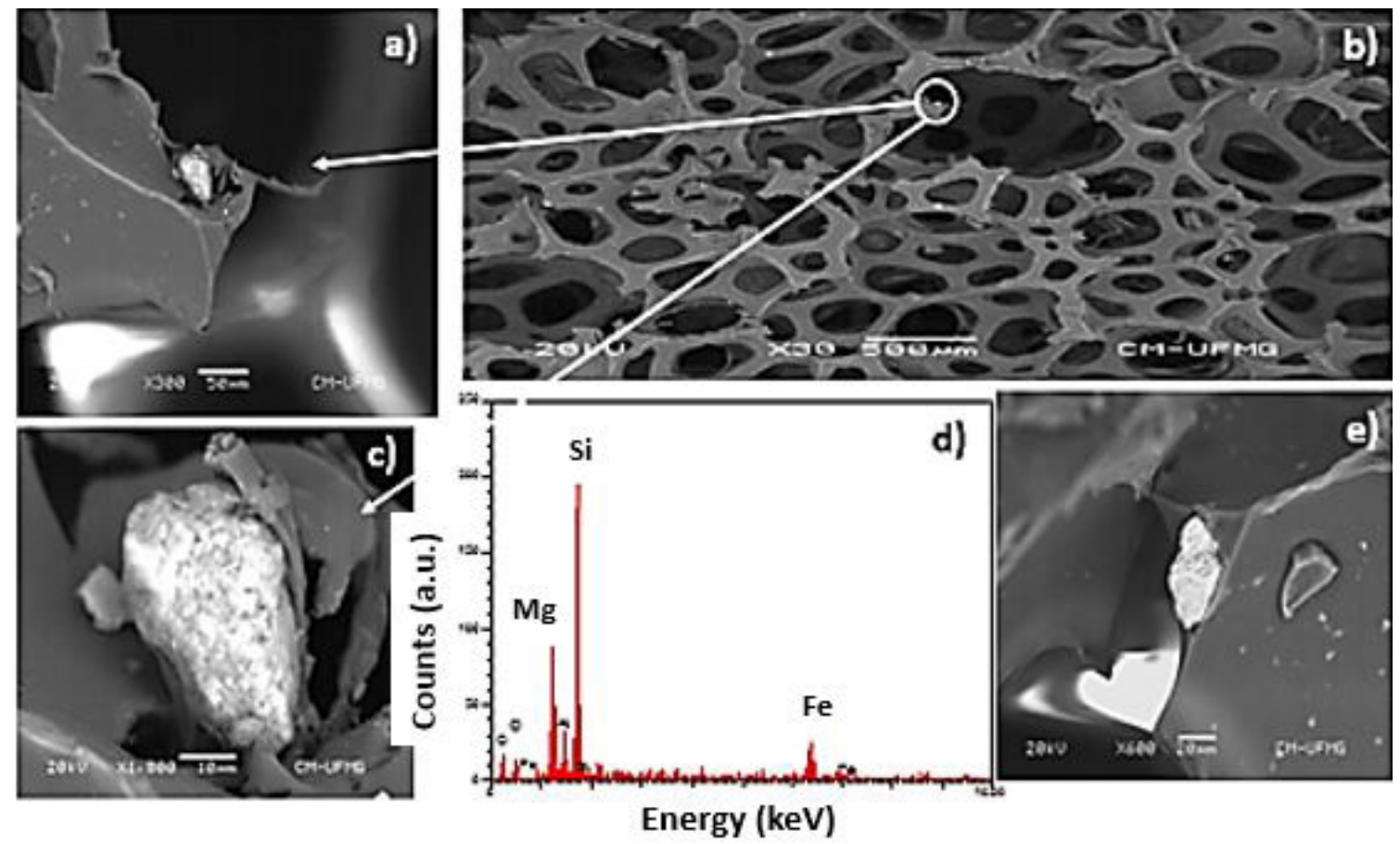

Figure 10. Composite images ( $a, b, c$ and e) obtained by scanning electron microscopy and EDS spectrum (d) of mineral particle (whiter particle).

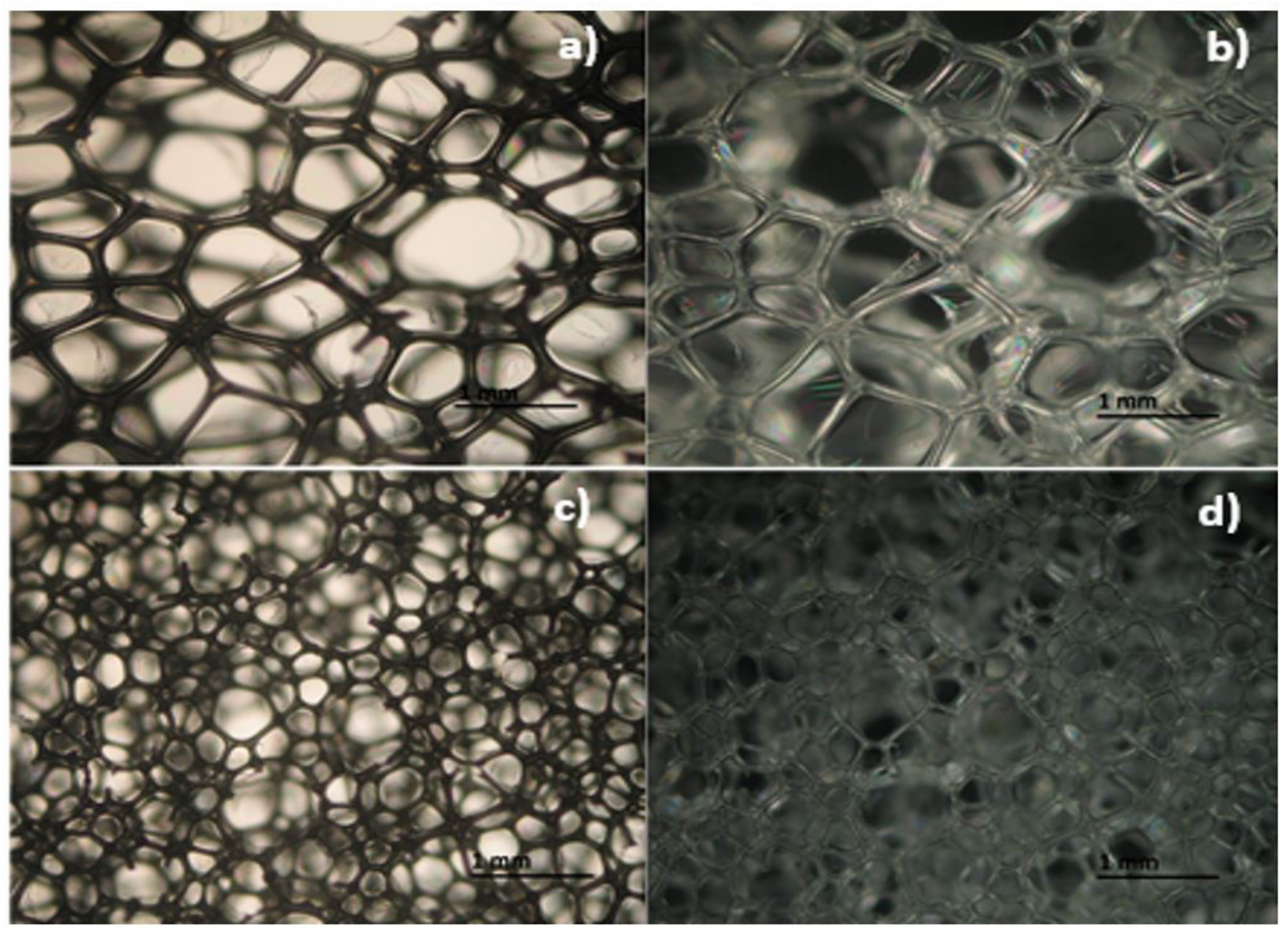

Figure 11. Composite images obtained by polarized light optical microscopy. Test 5 foam of the Table 2 seen in the microscope without crossed nicols (a) and under crossed nicols (b). Test 6 foam of the Table 2 seen in the microscope without crossed nicols (c) and under crossed nicols (d). 
promoting a greater amount of cross-linking (hard segments interconnected in a network) in the polymer chain ${ }^{[36,38]}$. Also, the polymer chain of the polyol contributes to the size of the polyurethane chain. In contrast, polyurethane grows on the surface of steatite, which serves as a center of nucleation and an additional point of cross-linking ${ }^{[2]}$.

Infrared spectrum of Figure 12 shows the bands related to the vibrational transition modes of the chemical groups of the polyurethane, demonstrating that the conversion of reactants to products has been successfully performed in the synthesis process. The band at $3288 \mathrm{~cm}^{-1}$ attributed to $v \mathrm{~N}-\mathrm{H}$ of urethane, $2970 \mathrm{~cm}^{-1}$ attributed to $v \mathrm{C}-\mathrm{H}$ of $\mathrm{CH}_{3}$, $2930 \mathrm{~cm}^{-1}$ attributed to $\mathrm{v}-\mathrm{H}$ of $\mathrm{CH}_{2}, 1724 \mathrm{~cm}^{-1}$ attributed to $\mathrm{V} C=\mathrm{O}$ of urethane and primary amide without hydrogen bond, $1716 \mathrm{~cm}^{-1}$ attributed to $\mathrm{vC}=\mathrm{O}$ of urethane and primary amide with hydrogen bond, $1640 \mathrm{~cm}^{-1}$ attributed to $v \mathrm{C}=\mathrm{O}$ of urea, $1598 \mathrm{~cm}^{-1}$ attributed to $\mathrm{vC}=\mathrm{C}$ of aromatic ring, $1540 \mathrm{~cm}^{-1}$ attributed to $\mathrm{VC}-\mathrm{N}$ and $\delta \mathrm{NH}$ of secondary amide, $1456 \mathrm{~cm}^{-1}$ attributed to $\delta \mathrm{CH}$ on the plan of $\mathrm{CH}_{2}, 1418 \mathrm{~cm}^{-1}$ attributed to $\mathrm{vC}-\mathrm{C}$ of aromatic ring, $1372 \mathrm{~cm}^{-1}$ attributed to $\delta \mathrm{CH}$ off-plan of $\mathrm{CH}_{2}, 1094 \mathrm{~cm}^{-1}$ attributed to $\mathrm{vC}-\mathrm{O}-\mathrm{C}$ of aliphatic ether. The bands between $900-650 \mathrm{~cm}^{-1}$ are assigned to the aromatic ring deformation modes ${ }^{[39-42]}$. The band $1640 \mathrm{~cm}^{-1}$ attributed to $\mathrm{vC}=\mathrm{O}$ of urea reflects the rigid segments of the foam. The hydrogen bond between the carbonyl corresponds to interaction between the rigid segments ${ }^{[42]}$. Therefore, the greater the intensity of the absorption band at $1640 \mathrm{~cm}^{-1}$, the greater the interaction between hard segments and, consequently, the greater the degree of separation of microphases (hard and soft segments) in the foam. Analyzing the absorption intensity of the band at $1640 \mathrm{~cm}^{-1}$ of normalized infrared spectrum for all foams, it is noted that foams with steatite have higher intensities than foams without the addition of steatite. Therefore, the increase of the hardness and the comfort factor of the foams by addition of steatite, is due to increased interaction between hard segments. These hydrogen bonds strengthen the phase connectivity and provide the hard urea segments with additional disruption choices under compression, which promotes chain slippage and mobility ${ }^{[7]}$. There is no significant difference in the chemical composition of the foams with $4.5 \mathrm{wt} \%$ or $0.0 \mathrm{wt}$. $\%$ of the steatite, according to their infrared spectra.

According to the Figure 13, the flexible polyurethane foams have three exothermic weight losses between $200{ }^{\circ} \mathrm{C}$ and $400{ }^{\circ} \mathrm{C}$ (DTA curve in blue identifying the exothermic peaks and the DTG curve in black identifying the mass variation), corresponding to approximately 88 wt. \%. The polyurethane heating causes its degradation into smaller nitrogen compounds such as hydrogen cyanide, acetonitrile, acrylonitrile, propionitrile, pyrrole, pyridine, aniline, benzonitrile, quinoline and phenyl isocyanate ${ }^{[43]}$. It occurs the breakdown of urethane linkages above $200^{\circ} \mathrm{C}$, and subsequently decompressing polyether chain between 250-320 ${ }^{\circ} \mathrm{C}$. At higher temperatures (around $375^{\circ} \mathrm{C}$ ), the polyether bonds are broken ${ }^{[44]}$. The last stage is the breakdown of the carbon chain ${ }^{[45]}$. Above $400{ }^{\circ} \mathrm{C}$ occurs final polymer degradation ${ }^{[11,46]}$. The foam 6 has a final residue of

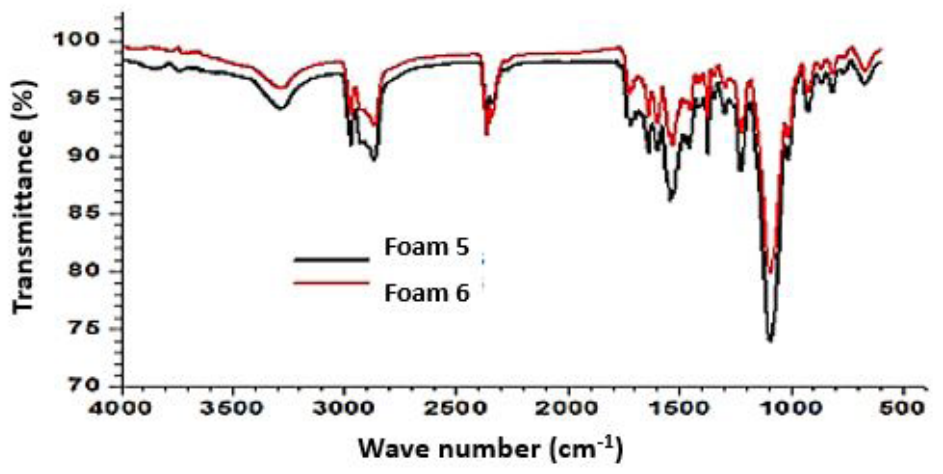

Figure 12. Infrared spectrum of the foams 5 and 6.
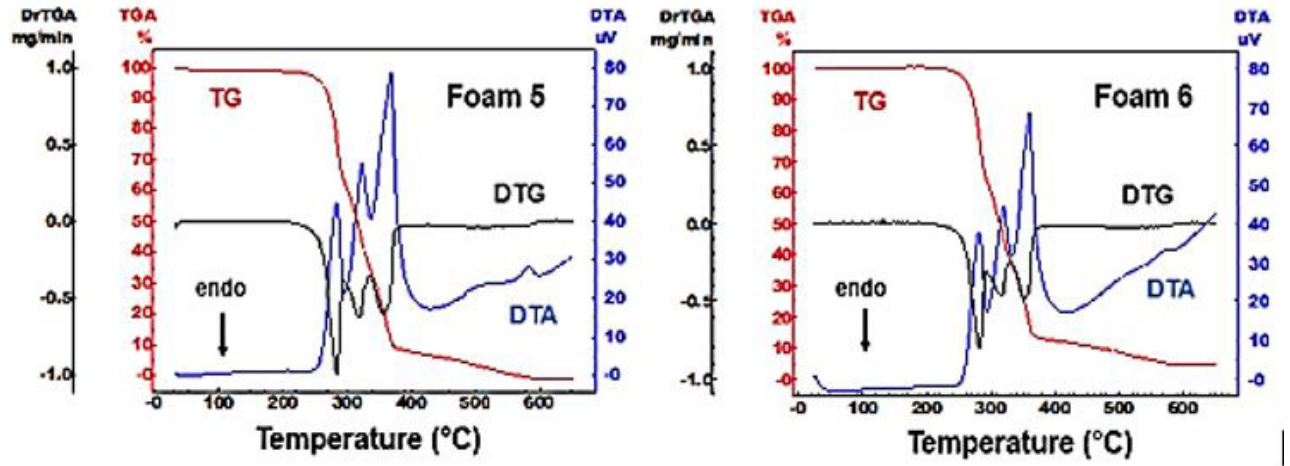

Figure 13. Thermal analysis of the foams 5 and 6 . 
4 wt. $\%$, due to the presence in the formulation of steatite. The foam 5 has no final residue, it is totally degraded by heating to $600{ }^{\circ} \mathrm{C}$. Therefore, foams having steatite has a higher ash content than traditional foams. In general, the thermal behavior of the foams during the heating does not change significantly, due to substitution of $4.5 \mathrm{wt}$. \% polyol by steatite. Thus, there is not a significant change in the chemical composition of the foam, due to addition of steatite.

\section{Conclusions}

The steatite rock is composed of attractive minerals for use in polyurethane synthesis, since it presents reactive hydroxyl and chemical properties useful as high thermal stability. The composites steatite/flexible polyurethane presented in relation to conventional foams, improvement in mechanical properties analyzed: comfort factor and support factor. Thus, foams with steatite are cheaper, have greater load support and increased comfort. There is not a significant change in the chemical composition of the foams, due to substitution of $4.5 \mathrm{wt}$. \% polyol by steatite. However, there was a decrease in cell size and greater interaction between the hard segments of the composite. The fractional factorial design showed be very useful and effective to test flexible polyurethane formulations. It enabled the study of the influence of each formulation component on the foams mechanical properties, as well as the influence of interactions between them. Sum up, the multivariate approach, in contrast of the univariate one, presents more comprehensive understanding of the investigated system through simultaneous evaluation of variables combined with a reduced number of experiments, that results in lower spending of reagents and laboratory time.

\section{Acknowledgements}

Thanks to CNPq and Pedras Congonhas Ltd. for financial support.

\section{References}

1. Mano, E. B., \& Mendes, L. C. (1999). Introdução a polímeros. São Paulo: Edgard Blücher Ltd.

2. Bernal, M. M., Lopez-Manchado, M. A., \& Verdejo, R. (2011). In situ foaming evolution of flexible polyurethane foam nanocomposites. Macromolecular Chemistry and Physics, 212(9), 971-979. http://dx.doi.org/10.1002/macp.201000748.

3. Wilkinson, A. N., Fithriyah, N. H., Stanford, J. L., \& Suckley, D. (2007). Structure development in flexible polyurethane foamlayered silicate nanocomposites. Macromolecular Symposia, 256(1), 65-72. http://dx.doi.org/10.1002/masy.200751007.

4. Andersson, A., Lundmark, S., Magnusson, A., \& Maurer, F. H. J. (2009). Shear behavior of flexible polyurethane foams under uniaxial compression. Journal of Applied Polymer Science, 111(5), 2290-2298. http://dx.doi.org/10.1002/app.29244.

5. Pavlicevic, J., Spirkova, M., Strachota, A., Szécsényi, K. M., Lazic, N., \& Budinski-Simendic, J. (2010). The influence of montmorillonite and bentonite addition on thermal properties of polyurethanes based on aliphatic polycarbonate diols. Thermochimica Acta, 509(1), 73-80. http://dx.doi.org/10.1016/j. tca.2010.06.005.

6. Bistricic, L., Baranovic, G., Leskovac, M., \& Bajsic, E. G. (2010). Hydrogen bonding and mechanical properties of thin films of polyether-based polyurethane-silica nanocomposites. European Polymer Journal, 46(10), 1975-1987. http://dx.doi. org/10.1016/j.eurpolymj.2010.08.001.

7. Ni, H., Yap, C. K., \& Jin, Y. (2007). Effect of curing moisture on the indentation force deflection of flexible polyurethane foam. Journal of Applied Polymer Science, 104(3), 1679-1682. http://dx.doi.org/10.1002/app.25798.

8. Rightor, E. G., Urquhart, S. G., Hitchcock, A. P., Ade, H., Smith, A. P., Mitchell, G. E., Priester, R. D., Aneja, A., Appel, G., Wilkes, G., \& Lidy, W. E. (2002). Identification and quantification of urea precipitates in flexible polyurethane foam formulations by X-ray spectromicroscopy. Macromolecules, 35(15), 5873-5882. http://dx.doi.org/10.1021/ma0122627.

9. Mello, D., Pezzin, S. H., \& Amico, S. C. (2009). The effect of post-consumer PET particles on the performance of flexible polyurethane foams. Polymer Testing, 28(7), 702-708. http:// dx.doi.org/10.1016/j.polymertesting.2009.05.014.

10. Singh, H., \& Jain, A. K. (2009). Ignition, combustion, toxicity, and fire retardancy of polyurethane foams: a comprehensive review. Journal of Applied Polymer Science, 111(2), 1115-1143.

11. Garrido, M. A., \& Font, R. (2015). Pyrolysis and combustion study of flexible polyurethane foam. Journal of Analytical and Applied Pyrolysis, 113, 202-215. http://dx.doi.org/10.1016/j. jaap.2014.12.017.

12. Gaan, S., Liang, S., Mispreuve, H., Perler, H., Naescher, R., \& Neisius, M. (2015). Flame retardant flexible polyurethane foams from novel DOPO-phosphonamidate additives. Polymer Degradation \& Stability, 113, 180-188. http://dx.doi. org/10.1016/j.polymdegradstab.2015.01.007.

13. Li, Y. C., Yang, Y. H., Shields, J. R., \& Davis, R. D. (2015). Layered double hydroxide-based fire resistant coatings for flexible polyurethane foam. Polymer, 56, 284-292. http:// dx.doi.org/10.1016/j.polymer.2014.11.023.

14. Nikje, M. M. A., Moghaddam, S. T., Noruzian, M., Nejad, M. A. F., Shabani, K., Haghshenas, M., \& Shakhesi, S. (2014). Preparation and characterization of flexible polyurethane foam nanocomposites reinforced by magnetic core-shell $\mathrm{Fe}_{3} \mathrm{O}_{4} @$ APTS nanoparticles. Colloid \& Polymer Science, 292(3), 627-633. http://dx.doi.org/10.1007/s00396-013-3099-2.

15. Polyurethane Foam Association. (1993). Compression modulus (support factor). INTOUCH ${ }^{\circledR}, 3(1), 1-4$. Retrieved in 2017, December 20, from http://pfa.org/intouch/index.html

16. Pérez-Maqueda, L. A., Duran, A., \& Pérez-Rodríguez, J. L. (2005). Preparation of submicron talc particles by sonication. Applied Clay Science, 28(1-4), 245-255. http://dx.doi. org/10.1016/j.clay.2004.01.012.

17. Kaggwa, G. B., Huynh, L., Ralston, J., \& Bremmell, K. (2006). The influence of polymer structure and morphology on talc wettability. Langmuir, 22(7), 3221-3227. http://dx.doi. org/10.1021/la052303i. PMid:16548581.

18. Nkoumbou, C., Villieras, F., Barres, O., Bihannic, I., Pelletier, M., Razafitianamaharavo, A., Metang, V., Yonta Ngoune, C., Njopwouo, D., \& Yvon, J. (2008). Physicochemical properties of talc ore from Pout-Kelle and Memel deposits (central Cameroon). Clay Minerals, 43(2), 317-337. http://dx.doi. org/10.1180/claymin.2008.043.2.11.

19. Dellisanti, F., Valdrè, G., \& Mondonico, M. (2009). Changes of the main physical and technological properties of talc due to mechanical strain. Applied Clay Science, 42(3), 398-404. http://dx.doi.org/10.1016/j.clay.2008.04.002.

20. Barros, B. B. No, Scarminio, I. S., \& Bruns, R. E. (2010). Como fazer experimentos: aplicações na ciência e na indústria. Campinas: Bookman.

21. Yoshida, M. I., Silva, V. R., Pinto, P. C. C., Sant'Anna, S. S., Silva, M. C., \& Carvalho, C. F. (2012). Physico-chemical characterization and thermal analysis data of alumina waste from 
Bayer process. Journal of Thermal Analysis and Calorimetry, 109(3), 1429-1433. http://dx.doi.org/10.1007/s10973-0111830-0.

22. Smolander, K., Saastamoinen, A., \& Ahlgrén, M. (1989). Determination of talc in geological samples by infrared spectrometry. Analytica Chimica Acta, 217, 353-358. http:// dx.doi.org/10.1016/S0003-2670(00)80417-1.

23. Gopal, N. O., Narasimhulu, K. V., \& Rao, J. L. (2004). Optical absorption, EPR, infrared and Raman spectral studies of clinochlore mineral. Journal of Physics and Chemistry of Solids, 65(11), 1887-1893. http://dx.doi.org/10.1016/j.jpcs.2004.07.003.

24. Gopal, N. O., Narasimhulu, K. V., \& Rao, J. L. (2004). EPR, optical, infrared and Raman spectral studies of Actinolite mineral. Spectrochimica acta. Part A, Molecular and Biomolecular Spectroscopy, 60(11), 2441-2448. http://dx.doi.org/10.1016/j. saa.2003.12.021. PMid:15294226.

25. Petit, S., Martin, F., Wiewiora, A., de Parseval, P., \& Decarreau, A. (2004). Crystal-chemistry of talc: a near infrared (NIR) spectroscopy study. The American Mineralogist, 89(2), 319326. http://dx.doi.org/10.2138/am-2004-2-310.

26. Yang, H., Du, C., Hu, Y., Jin, S., Yang, W., Tang, A., \& Avvakumov, E. G. (2006). Preparation of porous material from talc by mechanochemical treatment and subsequent leaching. Applied Clay Science, 31(3), 290-297. http://dx.doi. org/10.1016/j.clay.2005.10.015.

27. Martin, F., \& Micoud, P. (1999). The structural formula of talc from the Trimouns deposit, Pyrenées, France. Canadian Mineralogist, 37(4), 997-1006.

28. Zhang, M., Hui, Q., Lou, X. J., Redfern, S. A. T., Salje, E. K. H., \& Tarantino, S. C. (2006). Dehydroxylation, proton migration, and structural changes in heated talc: An infrared spectroscopic study. The American Mineralogist, 91(5), 816825. http://dx.doi.org/10.2138/am.2006.1945.

29. Wallqvist, V., Claesson, P. M., Swerin, A., Schoelkopf, J., \& Gane, P. A. C. (2009). Influence of wetting and dispersing agents on the interaction between talc and hydrophobic particles. Langmuir, 25(12), 6909-6915. http://dx.doi.org/10.1021/ la900192g. PMid:19334743.

30. Univar Polyurethane. (2017). Guia técnico de espumas flexiveis Univar $^{\circledR}$. Osasco: Univar. Retrieved in 2017, December 20 , from http://www.univar.com/pt-BR/Brazil/Industries/ /media/ PDFs/BR\%20Region\%20PDFs/Catalogos/POLYURETHANE/ COMPONENTES/Espumas\%20Flexiveis.ashx

31. Deer, W. A., Howie, R. A., \& Zussman, J. (1992). An introduction to the rock-forming minerals. Harlow: Pearson.

32. Michot, L. J., Villiéras, F., François, M., Yvon, J., Dred, R., \& Cases, J. M. (1994). The structural microscopic hydrophilicity of talc. Langmuir, 10(10), 3765-3773. http://dx.doi.org/10.1021/ la00022a061.

33. Pérez-Maqueda, L. A., Balek, V., Poyato, J., Subrt, J., Benes, M., Ramírez-Valle, V., Buntseva, I. M., Beckman, I. N., \& Pérez-Rodríguez, J. L. (2008). Transport properties and microstructure changes of talc characterized by emanation thermal analysis. Journal of Thermal Analysis and Calorimetry, 92(1), 253-258. http://dx.doi.org/10.1007/s10973-007-8819-8.

34. Balek, V., Pérez-Maqueda, L. A., Poyato, J., Cerný, Z., Ramírez-Valle, V., Buntseva, I. M., \& Pérez-Rodríguez, J. L. (2007). Effect of grinding on thermal reactivity of ceramic clay minerals. Journal of Thermal Analysis and Calorimetry, 88(1), 87-91. http://dx.doi.org/10.1007/s10973-006-8093-1.

35. Sonnenschein, M., Wendt, B. L., Schrock, A. K., Sonney, J. M., \& Ryan, A. J. (2008). The relationship between polyurethane foam microstructure and foam aging. Polymer, 49(4), 934-942. http://dx.doi.org/10.1016/j.polymer.2008.01.008.

36. Kaushiva, B. D., McCartney, S. R., Rossmy, G. R., \& Wilkes, G. L. (2000). Surfactant level influences on structure and properties of flexible slabstock polyurethane foams. Polymer, 41(1), 285-310. http://dx.doi.org/10.1016/S0032-3861(99)00135-4.

37. Zhang, X. D., Macosko, C. W., Davis, H. T., Nikolov, A. D., \& Wasan, D. T. (1999). Role of silicone surfactant in flexible polyurethane foam. Journal of Colloid and Interface Science, 215(2), 270-279. http://dx.doi.org/10.1006/jcis.1999.6233. PMid:10419661.

38. Dounis, D. V., \& Wilkes, G. L. (1997). Structure-property relationships of flexible polyurethane foams. Polymer, 38(11), 2819-2828. http://dx.doi.org/10.1016/S0032-3861(97)85620-0.

39. Tu, Y.C., Suppes, G. J., \& Hsieh, F.H. (2009). Thermal and mechanical behavior of flexible polyurethane-molded plastic films and water-blown foams with epoxidized soybean oil. Journal of Applied Polymer Science, 111(3), 1311-1317. http:// dx.doi.org/10.1002/app.29178.

40. Ludwick, A., Aglan, H., Abdalla, M. O., \& Calhoun, M. (2008). Degradation behavior of an ultraviolet and hygrothermally aged polyurethane elastomer: Fourier Transform infrared and differential scanning calorimetry studies. Journal of Applied Polymer Science, 110(2), 712-718. http://dx.doi.org/10.1002/ app. 28523 .

41. Barbosa, L. C. A. (2007). Espectroscopia no Infravermelho na caracterização de compostos orgânicos. Viçosa: Editora UFV.

42. Zhao, P. Z., Wang, Y. S., Zhu, J. H., Hua, X. Y., \& Wen, Q. Z. (2008). Characterization of graded polyurethane elastomer by FTIR. Science in China. Series B, Chemistry, 51(1), 58-61. http://dx.doi.org/10.1007/s11426-007-0093-x.

43. Herrera, M., Matuschek, G., \& Kettrup, A. (2002). Thermal degradation of thermoplastic polyurethane elastomers (TPU) based on MDI. Polymer Degradation \& Stability, 78(2), 323331. http://dx.doi.org/10.1016/S0141-3910(02)00181-7.

44. Ravey, M., \& Pearce, E. M. (1997). Flexible polyurethane foam I. Thermal decomposition of a polyether-based, water-blown commercial type of flexible polyurethane foam. Journal of Applied Polymer Science, 63(1), 47-74. http://dx.doi.org/10.1002/ (SICI) 1097-4628(19970103)63:1<47::AID-APP7>3.0.CO;2-S.

45. Spirckel, M., Regnier, N., Mortaigne, B., Youssef, B., \& Bunel, C. (2002). Thermal degradation and fire performance of new phosphonate polyurethanes. Polymer Degradation \& Stability, 78(2), 211-218. http://dx.doi.org/10.1016/S01413910(02)00135-0.

46. Allan, D., Daly, J., \& Liggat, J. J. (2013). Thermal volatilisation analysis of TDI-based flexible polyurethane foam. Polymer Degradation \& Stability, 98(2), 535-541. http://dx.doi. org/10.1016/j.polymdegradstab.2012.12.002.

Received: Dec. 20, 2017

Revised: Jan. 28, 2018 Accepted: Feb. 05, 2018 